\title{
Synthesis, Crystal Structures, and Molecular Properties of Three Nitro-Substituted Chalcones
}

\author{
Alam Yair Hidalgo ${ }^{1}\left(\mathbb{D}\right.$, Manuel Velasco ${ }^{1}$, Eduardo Sánchez-Lara ${ }^{2,+}{ }^{\circledR}$, Abraham Gómez-Rivera ${ }^{1}(\mathbb{D}$, \\ Miguel A. Vilchis-Reyes ${ }^{1}$, Cuauhtémoc Alvarado ${ }^{1}$, Maribel Herrera-Ruiz ${ }^{3}$, Ricardo López-Rodríguez ${ }^{1}(\mathbb{D}$, \\ Nancy Romero-Ceronio ${ }^{1, *}$ and Carlos E. Lobato-García ${ }^{1}$ [D
}

1 División Académica de Ciencias Básicas, Universidad Juárez Autónoma de Tabasco, Carretera Cunduacán-Jalpa Km 1, Col. La Esperanza, Cunduacan 86690, Tabasco, Mexico; alam.yair.hidalgo@gmail.com (A.Y.H.); manuel.velasco@ujat.mx (M.V.); abraham.gomez@ujat.mx (A.G.-R.); miguel.vilchis@ujat.mx (M.A.V.-R.); cuauhtemoc.alvarado@ujat.mx (C.A.); ricardo.lopezr@ujat.mx (R.L.-R.); carlos.lobato@ujat.mx (C.E.L.-G.)

2 Instituto de Ciencias, Benemérita Universidad Autónoma de Puebla, 18 Sur y Av. San Claudio, Col. San Manuel, Puebla 72570, Puebla, Mexico; esl_24@hotmail.com

3 Centro de Investigacion Biomédica del Sur, Instituto Mexicano del Seguro Social, Calle Rep. Argentina \#1, Xochitepec 62780, Morelos, Mexico; cibis_herj@yahoo.com.mx

* Correspondence: nancy.romero@ujat.mx

+ Currently unaffiliated to Benemérita Universidad Autónoma de Puebla.

\section{check for}

updates

Citation: Hidalgo, A.Y.; Velasco, M.; Sánchez-Lara, E.; Gómez-Rivera, A.; Vilchis-Reyes, M.A.; Alvarado, C.; Herrera-Ruiz, M.; López-Rodríguez, R.; Romero-Ceronio, N.;

Lobato-García, C.E. Synthesis, Crysta Structures, and Molecular Properties of Three Nitro-Substituted Chalcones. Crystals 2021, 11, 1589. https:// doi.org/10.3390/cryst11121589

Academic Editor: Duncan H. Gregory

Received: 22 October 2021

Accepted: 2 December 2021

Published: 20 December 2021

Publisher's Note: MDPI stays neutral with regard to jurisdictional claims in published maps and institutional affiliations.

Copyright: (c) 2021 by the authors. Licensee MDPI, Basel, Switzerland. This article is an open access article distributed under the terms and conditions of the Creative Commons Attribution (CC BY) license (https:// creativecommons.org/licenses/by/ $4.0 /)$.
Abstract: Three functionalized chalcones containing combinations of nitro functional groups have been synthesized via Claisen-Schmidt condensation between 2-nitroacetophenone and nitrobenzaldehyde, and the crystal structures obtained ((E)-1,3-bis(2-nitrophenyl)prop-2-en-1-one, 1a, (E)-1-(2nitrophenyl)-3-(3-nitrophenyl)prop-2-en-1-one, $\mathbf{1 b}$ and (E)-1-(2-nitrophenyl)-3-(4-nitrophenyl)prop2-en-1-one, 1c), $\mathrm{C}_{15} \mathrm{H}_{10} \mathrm{~N}_{2} \mathrm{O}_{5}$, are reported. Compounds 1a and 1c crystallized in the triclinic centrosymmetric space group $P \overline{1}$, whereas compound $\mathbf{1 b}$ crystallized in the orthorhombic space group Pbca. The X-ray analysis reveals that structures $\mathbf{1 a}$ and $\mathbf{1 b}$ exhibits s-trans conformation, whereas structure 1c exists in s-cis conformation, concerning the olefinic double bonds. In addition, the results show that the position of the nitro substituent attached to the aromatic B-ring has a direct effect on the molecular coplanarity of these compounds. The Hirshfeld surface analysis suggests that the non-covalent $\pi-\pi$ stacking interactions are the most important contributors for the crystal packing of $\mathbf{1 a}$ and $\mathbf{1 b}$. In $\mathbf{1 c}$, the crystal packing is mainly stabilized by weak intermolecular $\mathrm{C}-\mathrm{H} \cdots \mathrm{O}$ interactions due to the planar nature of the molecule.

Keywords: nitro chalcone; crystal structure; Hirshfeld surface; NMR-spectroscopy

\section{Introduction}

Chalcones (systematic name 1,3-diphenyl-2-propen-1-one) are unique structures found in a wide range of natural and synthetic compounds and are considered one of the privileged scaffolds in the field of medicinal chemistry for drug discovery. Naturally occurring chalcones are multisubstituted in the aryl rings by different groups, mainly hydroxyl, methoxy and alkenyl functions, while their synthetic analogs contain one or more aryl substituents such as halogens, alkyl, amine-, nitro-, nitril-, acetamide-, carboxylic groups, heterocyclic, benzene and condensed rings, etc [1-4]. Among these synthetic derivatives, the nitrochalcones have generated continuous interest among chemists and biochemists, mainly because of their applications in medicinal chemistry as potential antimicrobial, antihyperglycemic, antinociceptive, antitumor tools [5-13]. In this sense, in a previous report, we synthesized three nitro-substituted chalcones and evaluated their anti-inflammatory activity. We found that the chalcone with the nitro group at the ortho position develops the strongest anti-inflammatory protective effect, whereas the chalcone with the nitro group at the para position, showed the smallest effect [14]. Another important aspect of 
some nitro chalcones is that they can be used as intermediates for synthesizing various heterocyclic compounds like indoles, thioaurones, carbazoles, sultams, benzothiophenes, quinolines and indolin-3-ones [15-23]. On the other hand, the nitro chalcones also find application as chemosensors for anion sensing [24]. Additionally, the use of nitrochalcones as organogelators has also been reported [25].

Base on the above, it is of our interest to synthesize nitro-substituted chalcones due to their potential properties. Therefore, we herein report the synthesis, $\mathrm{X}$-ray crystal structure studies and Hirshfeld surface analysis of three nitrochalcone derivatives.

\section{Materials and Methods}

\subsection{General}

All chemicals were purchased from Sigma Aldrich (Toluca, Mexico). All manipulations were carried out at room temperature with no special solvent and reagent purification. Melting points were determined on a Stuart SMP10 apparatus by the open capilar technique and are uncorrected. ${ }^{1} \mathrm{H}$ NMR and DEPTQ NMR spectra were recorded at $600 \mathrm{MHz}$ and $150 \mathrm{MHz}$, respectively, in DMSO- $d_{6}$ using a Bruker Ascend ${ }^{\mathrm{TM}}$ Spectrometer. Chemical shifts are given in ppm and reported to the residual solvent peak (DMSO- $d_{6}: 2.50 \mathrm{ppm}$ for ${ }^{1} \mathrm{H}$ and $39.51 \mathrm{ppm}$ for ${ }^{13} \mathrm{C}$ ). Data are reported as follows: chemical shift ( $\left.\delta\right)$, multiplicity ( $\mathrm{s}=$ singlet, $\mathrm{d}=$ doublet, $\mathrm{t}=$ triplet, $\mathrm{m}=$ multiplet $)$, coupling constant $(\mathrm{s})(\mathrm{J}, \mathrm{Hz})$ and integration. Analytical TLC was performed on silica gel 60 F254 plates. IR spectra were obtained using an FT-IR spectrometer, Spectrum One, Perkin Elmer.

\subsection{X-ray Crystallography}

Single crystals of 1a-1c, suitable for X-ray study, were purified by a two-solvent recrystallization technique at room temperature. Data collection was performed using the Stoe Stadivari diffractometer equipped with an Axo microfocus source Ag-K $\alpha(\lambda=0.56083 \AA)$ and a Dectris Pilatus-100K detector. The absorption correction for the three compounds was realized using measurements of symmetry-related intensities (X-AREA [26]). Structure solutions were obtained using direct methods implemented in SHELXS [27], and the final refinement was performed with full-matrix least-squares on $F^{2}$ using SHELXL [27]. In the case of 1c, a positional disorder was resolved for the carbonyl atom O7, which was split over two positions, O7a and O7b, with refined occupancies 0.41(4) and 0.59(4). The programs ORTEP-3 [28] SHELXS/SHELXL [27] were used within the WinGX [28] software package. All hydrogen atoms were placed in calculated positions and refined as riding on their parent $\mathrm{C}$ atoms, with $\mathrm{C}-\mathrm{H}=0.95 \AA$ (1a) or $\mathrm{C}-\mathrm{H}=0.93 \AA(\mathbf{1 b}-\mathbf{c})$. All H atoms were refined isotropically, with $U_{\text {iso }}(\mathrm{H})=1.2 U$ eq (carrier $\mathrm{C}$ ). Geometric parameters of 1a-1c were validated and studied through the Mercury [29] and Platon [30] software. Crystal data, data collection and structure refinement details are summarized in Table 1. Crystallographic information files for the three chalcone derivatives were deposited in the Cambridge Structural Database [31] under codes 2036696, 2036697 and 2036695, respectively. Copies of data can be obtained free of charge at https:/ /www.ccdc.cam.ac.uk/ (accessed on 29 October 2021).

Table 1. Single crystal data and structure refinement details for compounds $\mathbf{1 a}, \mathbf{1} \mathbf{b}$ and $\mathbf{1 c}$.

\begin{tabular}{llll}
\hline & $\mathbf{1 a}$ & $\mathbf{1 b}$ & $\mathbf{1 c}$ \\
\hline Empirical formula & $\mathrm{C}_{15} \mathrm{H}_{10} \mathrm{~N}_{2} \mathrm{O}_{5}$ & $\mathrm{C}_{15} \mathrm{H}_{10} \mathrm{~N}_{2} \mathrm{O}_{5}$ & $\mathrm{C}_{15} \mathrm{H}_{10} \mathrm{~N}_{2} \mathrm{O}_{5}$ \\
Formula weight & 298.25 & 298.25 & 298.25 \\
Crystal system & Triclinic & Orthorhombic & Triclinic \\
$\mathrm{T}(\mathrm{K})$ & $123(1)$ & $295(1)$ & $295(1)$ \\
Space group & $P \overline{1}$ & $P b c a$ & $P \overline{1}$ \\
CCDC-Numbers & 2036696 & 2036697 & 2036695 \\
\hline
\end{tabular}


Table 1. Cont.

\begin{tabular}{llll}
\hline & $\mathbf{1 a}$ & $\mathbf{1 b}$ & $\mathbf{1 c}$ \\
\hline Conformation & $s$-trans & s-trans & s-cis \\
$a[\AA]$ & $7.6303(4)$ & $11.1553(4)$ & $7.6817(9)$ \\
$b[\AA]$ & $7.8424(5)$ & $14.1772(5)$ & $7.8867(7)$ \\
$\mathrm{c}[\AA]$ & $12.5262(8)$ & $17.6747(8)$ & $12.4081(13)$ \\
$\alpha(\mathrm{deg})$ & $94.327(5)$ & 90 & $84.587(8)$ \\
$\beta(\mathrm{deg})$ & $90.696(5)$ & 90 & $74.210(9)$ \\
$\gamma(\mathrm{deg})$ & $117.716(4)$ & 90 & $69.877(8)$ \\
$\mathrm{V}\left(\AA^{3}\right)$ & $660.72(7)$ & $2795.27(19)$ & $679.20(13)$ \\
$Z$ & 2 & 8 & 2 \\
Radiation type & $0.56083 \AA$ & 0.56083 & 0.56083 \\
$\theta$ range & 2.430 to $23.000^{\circ}$ & 2.320 to $21.498^{\circ}$ & 2.553 to $21.497^{\circ}$ \\
$D_{\text {calc. }}\left(\mathrm{g} / \mathrm{cm}{ }^{3}\right)$ & 1.499 & 1.417 & 1.458 \\
$\mu\left(\mathrm{mm}{ }^{-1}\right)$ & 0.070 & 0.067 & 0.068 \\
Transm. factors & $0.572-1.000$ & $0.428-1.000$ & $0.429-1.000$ \\
Reflections collected & 16132 & 61499 & 14368 \\
Independent reflections & 3743 & 3270 & 3166 \\
Parameters & 199 & 200 & 209 \\
$R_{\text {int }}$ & 0.0241 & 0.0527 & 0.0429 \\
Goodness-of-fit on $F^{2}$ & 1.086 & 1.012 & 0.892 \\
Final R index $[I>2 \sigma(I)]$ & 0.0354 & 0.0386 & 0.0424 \\
$w R_{2}($ all data) & 0.1002 & 0.1119 & 0.1199 \\
Largest diff. peak and hole $\left(\mathrm{e} / \AA^{3}\right)$ & $0.341,-0.235$ & $0.166,-0.174$ & $0.230,-0.187$ \\
\hline
\end{tabular}

\subsection{General Procedure: Synthesis of Nitro Chalcones Derivatives (1a-1c)}

To a stirred solution of 2-nitroacetophenone $(10 \mathrm{mmol})$ in ethanol $(10 \mathrm{~mL})$ was added a solution of sodium hydroxide $(6 \mathrm{~mL}, 1.0 \mathrm{M})$ in an ice-salt bath. After stirring for $15 \mathrm{~min}$, the appropriate nitrobenzaldehyde was added and the reaction mixture was stirred for $3 \mathrm{~h}$ at room temperature. The progress of the reaction was monitored by TLC. The product obtained was filtered, washed with water and recrystallized by a solvent pair (dichloromethane $/ n$-hexane), which gave the desired nitro chalcone 1.

(E)-1,3-bis(2-nitrophenyl)prop-2-en-1-one 1a. Obtained in $42 \%$ yield as a white solid; mp: 140-142 ${ }^{\circ} \mathrm{C}$ [lit. $136-137^{\circ} \mathrm{C}$ ] [32]; ${ }^{1} \mathrm{H}$ NMR $\left(600 \mathrm{MHz}\right.$, DMSO- $\left.d_{6}\right) \delta=8.25(\mathrm{~d}, J=8.1 \mathrm{~Hz}, 1 \mathrm{H})$, $8.08(\mathrm{~d}, J=8.1 \mathrm{~Hz}, 1 \mathrm{H}), 8.01(\mathrm{~d}, J=7.7 \mathrm{~Hz}, 1 \mathrm{H}), 7.95(\mathrm{t}, J=7.3 \mathrm{~Hz}, 1 \mathrm{H}), 7.85-7.80(\mathrm{~m}, 2 \mathrm{H})$, $7.75(\mathrm{~d}, J=7.4 \mathrm{~Hz}, 1 \mathrm{H}), 7.70(\mathrm{t}, J=7.9 \mathrm{~Hz}, 1 \mathrm{H}), 7.66(\mathrm{~d}, J=16.1 \mathrm{~Hz}, 1 \mathrm{H}), 7.24(\mathrm{~d}, J=16.1 \mathrm{~Hz}$, $1 \mathrm{H})$; DEPTQ NMR $\left(150 \mathrm{MHz}\right.$, DMSO- $\left.d_{6}\right) \delta=192.6,148.8,146.9,141.6,135.3,135.1,134.4$, 132.2, 131.8, 130.0, 129.8, 129.7, 129.6, 125.3, 125.1. FTIR: $v_{\max } / \mathrm{cm}^{-1}: 1658(\mathrm{C}=\mathrm{O}), 1516$ $(\mathrm{C}=\mathrm{C}), 1333(\mathrm{~N}-\mathrm{O}), 977(\mathrm{C}=\mathrm{C}$ trans $)$.

(E)-1-(2-nitrophenyl)-3-(3-nitrophenyl)prop-2-en-1-one $\mathbf{1 b}$. Obtained in $90 \%$ yield as a white solid; mp: $145-147{ }^{\circ} \mathrm{C}$ [lit. $143-145^{\circ} \mathrm{C}$ ] [32]; ${ }^{1} \mathrm{H}$ NMR $\left(600 \mathrm{MHz}, \mathrm{DMSO}-d_{6}\right) \delta=8.58$ $(\mathrm{s}, 1 \mathrm{H}), 8.25-8.22(\mathrm{~m}, 3 \mathrm{H}), 7.92(\mathrm{t}, J=7.4 \mathrm{~Hz}, 1 \mathrm{H}), 7.83(\mathrm{t}, J=7.7 \mathrm{~Hz}, 1 \mathrm{H}), 7.74(\mathrm{~d}, J=7.4 \mathrm{~Hz}$, $1 \mathrm{H}), 7.70(\mathrm{t}, J=7.9 \mathrm{~Hz}, 1 \mathrm{H}), 7.57(\mathrm{~d}, J=16.3 \mathrm{~Hz}, 1 \mathrm{H}), 7.51(\mathrm{~d}, J=16.3 \mathrm{~Hz}, 1 \mathrm{H})$; DEPTQ NMR $\left(150 \mathrm{MHz}, \mathrm{DMSO}-d_{6}\right) \delta=192.6,148.7,147.0,143.6,136.3,135.6,135.0,134.9,132.0,130.8$, 129.5, 128.6, 125.4, 125.0, 123.9. FTIR: $\gamma_{\max } / \mathrm{cm}^{-1}: 1650(\mathrm{C}=\mathrm{O}), 1523(\mathrm{C}=\mathrm{C}), 1345(\mathrm{~N}-\mathrm{O})$, 983 (C=C trans).

(E)-1-(2-nitrophenyl)-3-(4-nitrophenyl)prop-2-en-1-one 1c. Obtained in $81 \%$ yield as a yellow solid; mp: $175-177{ }^{\circ} \mathrm{C}$ [lit. $168-169{ }^{\circ} \mathrm{C}$ ] [32]; ${ }^{1} \mathrm{H}$ NMR $\left(600 \mathrm{MHz}, \mathrm{DMSO}-d_{6}\right)$ $\delta=8.24-8.22(\mathrm{~m}, 3 \mathrm{H}), 8.01(\mathrm{~m} .2 \mathrm{H}), 7.93(\mathrm{t}, J=7.4 \mathrm{~Hz}, 1 \mathrm{H}), 7.83(\mathrm{t}, J=7.7 \mathrm{~Hz}, 1 \mathrm{H}), 7.76(\mathrm{~d}$, $J=7.4 \mathrm{~Hz}, 1 \mathrm{H}), 7.53(\mathrm{~d}, J=16.2 \mathrm{~Hz}, 1 \mathrm{H}), 7.48(\mathrm{~d}, J=16.2 \mathrm{~Hz}, 1 \mathrm{H})$; DEPTQ NMR $(150 \mathrm{MHz}$, DMSO- $\left.d_{6}\right) \delta=192.5,148.7,147.0,143.1,140.8,135.4,135.0,132.1,130.3,129.7,129.5,125.1$, 124.3. FTIR: $v_{\max } / \mathrm{cm}^{-1}: 1667(\mathrm{C}=\mathrm{O}), 1511(\mathrm{C}=\mathrm{C}), 1334(\mathrm{~N}-\mathrm{O}), 983(\mathrm{C}=\mathrm{C}$ trans $)$. 


\section{Results and Discussion}

\subsection{Chemistry}

The synthetic route of the proposed compound 1a-1c is shown in Scheme 1. The nitro chalcone derivatives were obtained by the reaction of 2-nitroacetophenone with the appropriate nitrobenzaldehyde in the presence of an alcoholic basic medium [14]. All the compounds were recrystallized using a solvent pair. The yield of the compounds after recrystallization ranged from 42 to $90 \%$. In ${ }^{1} \mathrm{H}$ NMR spectra, the values of the coupling constants between $\mathrm{H}_{\alpha}$ and $\mathrm{H}_{\beta}(\mathrm{J}=16.1-16.3 \mathrm{~Hz})$ confirm that, for this reaction, the products generated were only E-isomers. The ${ }^{1} \mathrm{H}(600 \mathrm{MHz})$ and DEPTQ $(150 \mathrm{MHz}) \mathrm{NMR}$. Spectra are presented in Supplementary Materials (Figures S1-S6). The infrared spectra of the synthesized compounds 1a-1c exhibited similar spectral patterns (Figure S7). The IR peaks observed are consistent with the functional groups present in the compound and hence, support the structure of 1a-1c. Table S1 shows the assignments of the main bands [33].

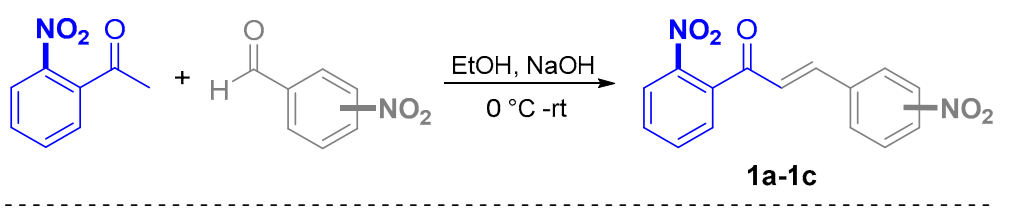<smiles>O=C(/C=C/c1ccccc1[N+](=O)[O-])c1ccccc1[N+](=O)[O-]</smiles>

1a $42 \%$<smiles>O=C(/C=C/c1cccc([N+](=O)[O-])c1)c1ccccc1[N+](=O)[O-]</smiles>

1b $90 \%$<smiles>O=C(/C=C/c1ccc([N+](=O)[O-])cc1)c1ccccc1[N+](=O)[O-]</smiles>

Scheme 1. The synthesis of compounds.

It is important to mention that the behavior observed in the melting points values for the isomers reported as $\mathbf{1 a}-\mathbf{c}$ can be described as follows: the isomers $\mathbf{1 a}$ and $\mathbf{1} \mathbf{b}$ present very similar melting points, but in the case of isomer $\mathbf{1 c}$, this physical constant is higher. We can attribute this difference in the melting points values to the fact that the latter isomer presents the flattest conformation, which allows a better packing in the crystalline lattice, thereby increasing the melting point.

\subsection{Structural Description}

Compound 1a crystallized triclinic with the space group $P \overline{1}$ (Table 1). The asymmetric unit contains two nitro-substituted aromatic rings in the ortho position, joined by a threecarbon $\alpha, \beta$-unsaturated carbonyl system (Figure 1). The molecule adopts the most stable s-trans conformation with respect to the $C 8=C 9$ [1.336(14) $\AA]$ and C7=O7 [1.217(12) $\AA]$ functional groups, located in the enone moiety [34]. The structure is twisted around the $\mathrm{C} 1^{\prime}-\mathrm{C} 7$ and $\mathrm{C} 9-\mathrm{C} 1$ single bonds with torsion angles of $79.82(13)^{\circ}$ and $142.81(11)^{\circ}$ for $\mathrm{C} 8-\mathrm{C} 7-\mathrm{C}^{\prime}-\mathrm{C} 2^{\prime}$ and $\mathrm{C} 2-\mathrm{C} 1-\mathrm{C} 9-\mathrm{C} 8$, respectively. The molecule adopts a conformation in which the $-\mathrm{NO}_{2}$ groups are closer to each other, generating a slightly more compact asymmetric unit compared to compounds $\mathbf{1 b}$ and $\mathbf{1 c}$, which have a more extended molecular backbone (see below). Therefore, this structure can be considered thermodynamically less stable compared with compounds $\mathbf{1 b}$ and $\mathbf{1 c}$. 


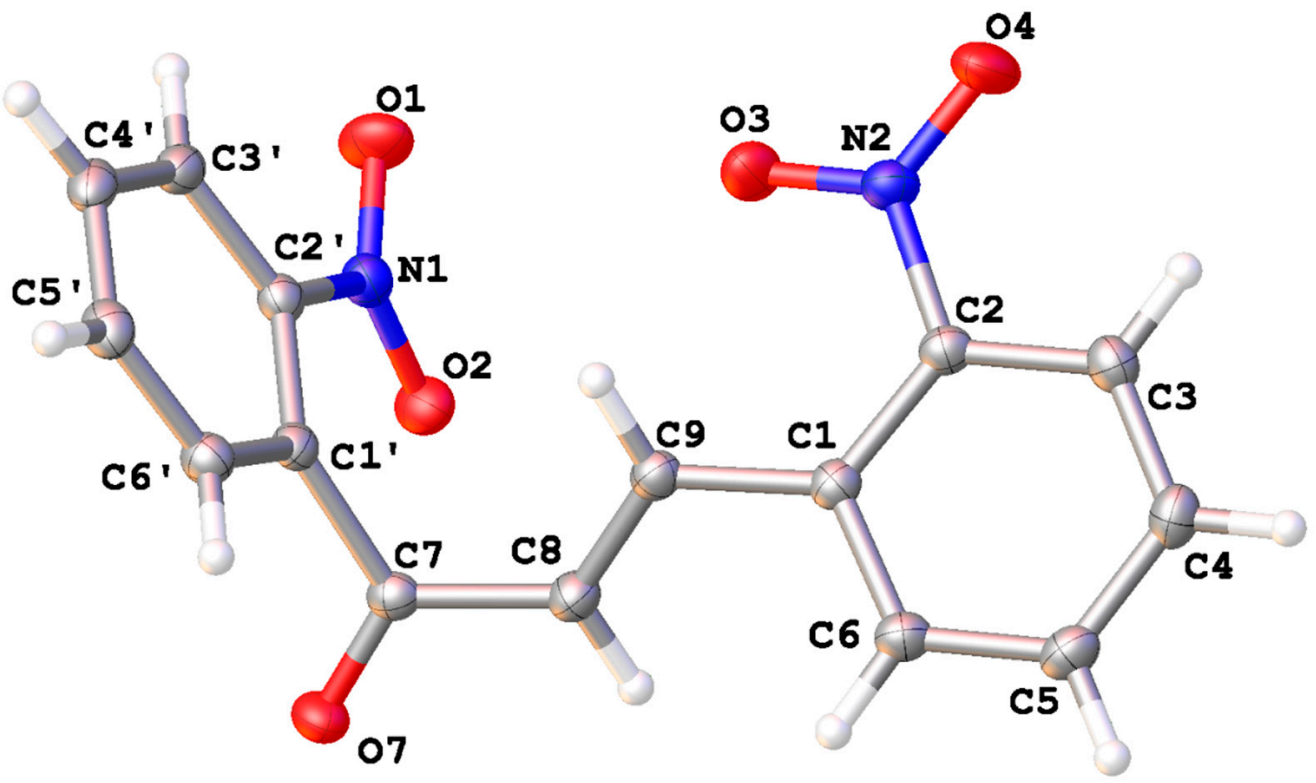

Figure 1. The molecular structure of compound 1a, with displacement ellipsoids drawn at the $50 \%$ probability level. $\mathrm{H}$ atoms are shown as small spheres of arbitrary radius.

A quick analysis in Mogul geometry check [29] confirms the deviation of the torsion angles, $\mathrm{C} 8-\mathrm{C} 7-\mathrm{C}^{\prime}-\mathrm{C} 2^{\prime}\left[79.82(13)^{\circ}\right]$ and $\mathrm{O} 7-\mathrm{C} 7-\mathrm{C}^{\prime}-\mathrm{C}^{\prime}\left[72.54(13)^{\circ}\right]$, from the typical values found in chalcone derivatives. Out of 48 crystal structures analyzed from the Mogul library of the CSD [35], only three crystal structures (CSD refcodes: CNCHAL, BRNICH and NIPFUP) with at least one nitro-substituted aromatic ring have torsion angles similar to those of compound 1a $[36,37]$. From these data, we can deduce that nitro groups have a direct effect on the degree of torsion of the molecule. This is more evident in this compound due to the electro-withdrawing groups that are in the ortho position in both aromatic systems [38]. As we shall see, as long as the aromatic B-ring changes its substitution pattern, the molecules assume a greater planar character. On the other hand, the two aromatic systems related by the enone group form a dihedral angle of $63.21(4)^{\circ}$. Finally, the nitro groups slightly deviate from the main planes of the aromatic rings with torsion angles of 13.35 $(14)^{\circ}$ and $-9.86(15)^{\circ}$ for $\mathrm{O} 2-\mathrm{N} 1-\mathrm{C}^{\prime}-\mathrm{C}^{\prime}$ and $\mathrm{O} 3-\mathrm{N} 2-\mathrm{C} 2-\mathrm{C} 1$, respectively.

Compound $\mathbf{1 b}$ crystallizes orthorhombic with space group Pbca (Table 1). Unlike compound 1a, the aromatic rings are nitro-substituted in ortho and meta-positions, which are connected through the $-\mathrm{C}=\mathrm{C}-\mathrm{C}=\mathrm{O}$ planar system (Figure 2). Both $\mathrm{NO}_{2}$-substituents are coplanar with the aromatic rings $\left[\mathrm{O} 2-\mathrm{N} 1-\mathrm{C}^{\prime}-\mathrm{C}^{\prime}=-1.3(2)^{\circ}\right.$ and $\left.\mathrm{O} 3-\mathrm{N} 2-\mathrm{C} 3-\mathrm{C} 2=-9.0(2)^{\circ}\right]$ The change in the substitution pattern (from ortho-to-meta) in the aromatic B-ring causes the molecule to adopt a planar moiety, and both the central enone group and the $\mathrm{C} 1-\mathrm{C} 6$ aromaticring are nearly coplanar, with a torsion angle $\mathrm{C} 8-\mathrm{C} 9-\mathrm{C} 1-\mathrm{C} 2$ of $-163.35(15)^{\circ}$. In contrast, the aromatic A-ring makes a torsion angle $\mathrm{C}^{\prime}-\mathrm{C}^{\prime}-\mathrm{C} 7-\mathrm{C} 8$ with the $-\mathrm{C}=\mathrm{C}-\mathrm{C}=\mathrm{O}$ central group of $90.33(19)^{\circ}$. The distancing of the aromatic rings makes the nitro groups tend to be far apart from each other, minimizing the repulsive van der Waals forces. The torsion angles formed between the enone unit and the aromatic rings are also outside typical values; however, this is expected, considering the effect of the $\mathrm{NO}_{2}$-substituent on the geometric parameters of the molecule. Compound $\mathbf{1 b}$ exists in the stereoselective s-trans conformation with respect to the $\mathrm{C} 8=\mathrm{C} 9[1.324(2) \AA]$ and $\mathrm{C} 7=\mathrm{O} 7[1.217(18) \AA]$ double bonds. Apparently, this conformation is the predominant form in crystallized chalcone derivatives molecules with low planarity [39-42]. 


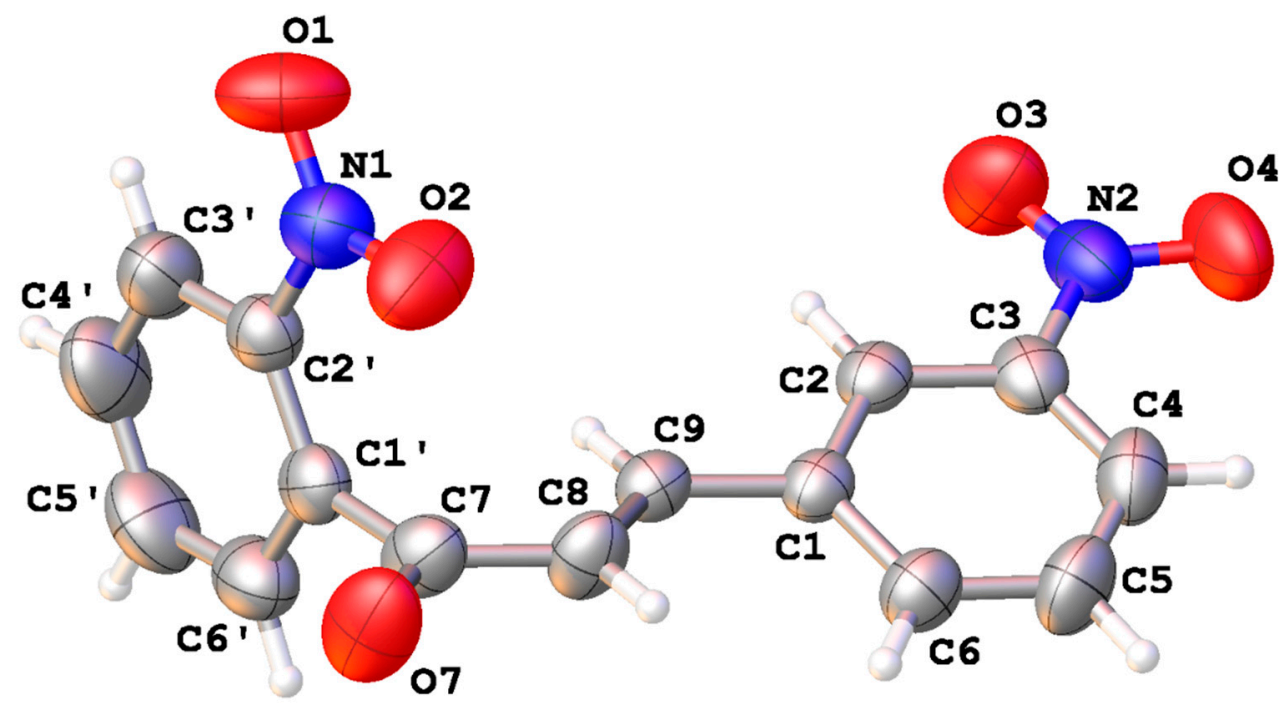

Figure 2. The molecular structure of compound $\mathbf{1 b}$, with displacement ellipsoids drawn at the $50 \%$ probability level. H atoms are shown as small spheres of arbitrary radius.

Compound 1c crystallized triclinic with space group $P \overline{1}$ (Table 1 ). The geometry of the molecule is imposed by the change of position of the nitro substituent bonded to the $\mathrm{C} 4$, which is in para position to the $\alpha, \beta$-unsaturated carbonyl system (Figure 3). The aromatic A-ring retains the ortho substitution pattern in a similar way to compounds $\mathbf{1 a}$ and $\mathbf{1} \mathbf{b}$. The torsion angles between the atoms $\mathrm{C} 8-\mathrm{C} 9-\mathrm{C} 1-\mathrm{C} 6$ and $\mathrm{C} 8-\mathrm{C} 7-\mathrm{C} 1^{\prime}-\mathrm{C} 2^{\prime}$ are $177.6(2)^{\circ}$ and $165.62(15)^{\circ}$, respectively, indicating that the substituted aromatic systems and the central enone unit are coplanar. Therefore, the molecule adopts the s-cis conformation with respect to the $\mathrm{C} 8=\mathrm{C} 9[1.321(2) \AA]$ and $\mathrm{C} 7=\mathrm{O} 7 \mathrm{~B}[1.214(7) \AA]$ double bonds, with a torsion angle $\mathrm{C} 1^{\prime}-\mathrm{C} 7-\mathrm{C} 8-\mathrm{C} 9$ of $-178.78(17)^{\circ}$. In contrast to compounds $\mathbf{1 a}$ and $\mathbf{1 b}$, the planarity of compound $1 \mathrm{c}$ favors the s-cis conformation, which is present in crystallized chalcone derivatives with a planar backbone [43-45].

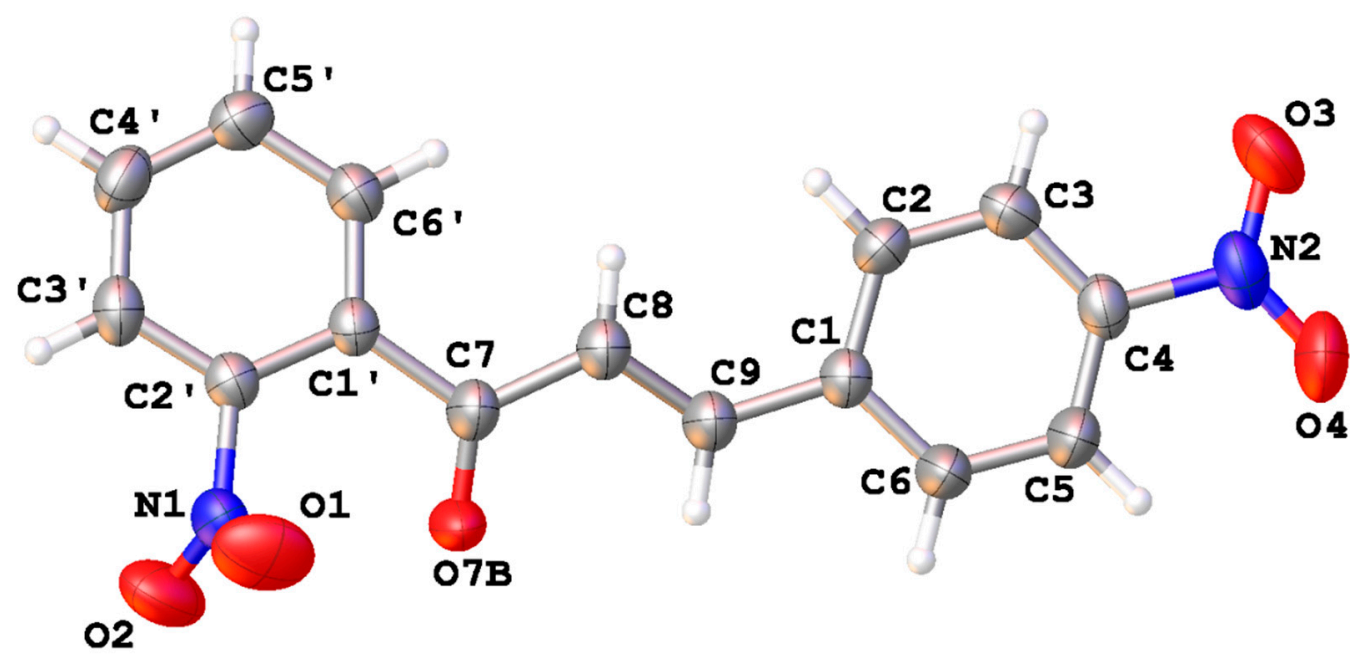

Figure 3. The molecular structure of compound 1c, with displacement ellipsoids drawn at the 50\% probability level. H atoms are shown as small spheres of arbitrary radius.

On the other hand, the dihedral angle formed between the main planes from the aromatic rings is $11.38(18)^{\circ}$, which is comparatively smaller than those found in $\mathbf{1 a}$ and $\mathbf{1 b}$. In the molecule, the nitro substituent attached to $\mathrm{C} 4$ is coplanar with the aromatic system, with a small torsion angle $\mathrm{O} 4-\mathrm{N} 2-\mathrm{C} 4-\mathrm{C} 5$ of $3.5(3)^{\circ}$, while the nitro group attached to $\mathrm{C} 2^{\prime}$ rotates out of the aromatic plane with a torsion angle of $69.1(2)^{\circ}$ in order to minimize electrostatic repulsions with the $\mathrm{C} 7=\mathrm{O} 7 \mathrm{~B}$ carbonyl functional group. 


\subsection{Supramolecular Features}

Through the molecular packing diagram of compound 1a, we can observe that both aromatic rings are involved in attractive stacking interactions with neighboring molecules placed around inversion centers from the crystallographic space group. These noncovalent interactions seem to dominate the supramolecular structure of this compound due to the lack of conventional hydrogen bonds. In this sense, the $\mathrm{C}^{\prime}-\mathrm{C} 6^{\prime}$ aromatic rings are stacked in a parallel-displaced fashion along the [1] direction, and the separation between the centroids of this $\pi$-systems is $3.647(2) \AA$, while the $\mathrm{C} 1-\mathrm{C} 6$ aromatic rings are stacked in the same conformation with a centroid-to-centroid distance of 3.729(2) $\AA$ (Figure 4). In this scheme, the $\mathrm{C}^{\prime}-\mathrm{C} 6^{\prime}$ aromatic ring seems to establish two shorth $\mathrm{C}-\mathrm{H} \cdots \mathrm{O}$ contacts with the carbonyl and nitro-group as acceptors, with intermolecular distances of 2.680(7) $\AA$ and 2.579(8) $\AA$ for $\mathrm{C}^{\prime}-\mathrm{H}^{\prime} \cdots \mathrm{O} 7$ and $\mathrm{C} 4^{\prime}-\mathrm{H} 4^{\prime} \cdots \mathrm{O} 2$, respectively, but with angles (D-H $\left.\cdots \mathrm{A}\right)$ less than $154^{\circ}$.

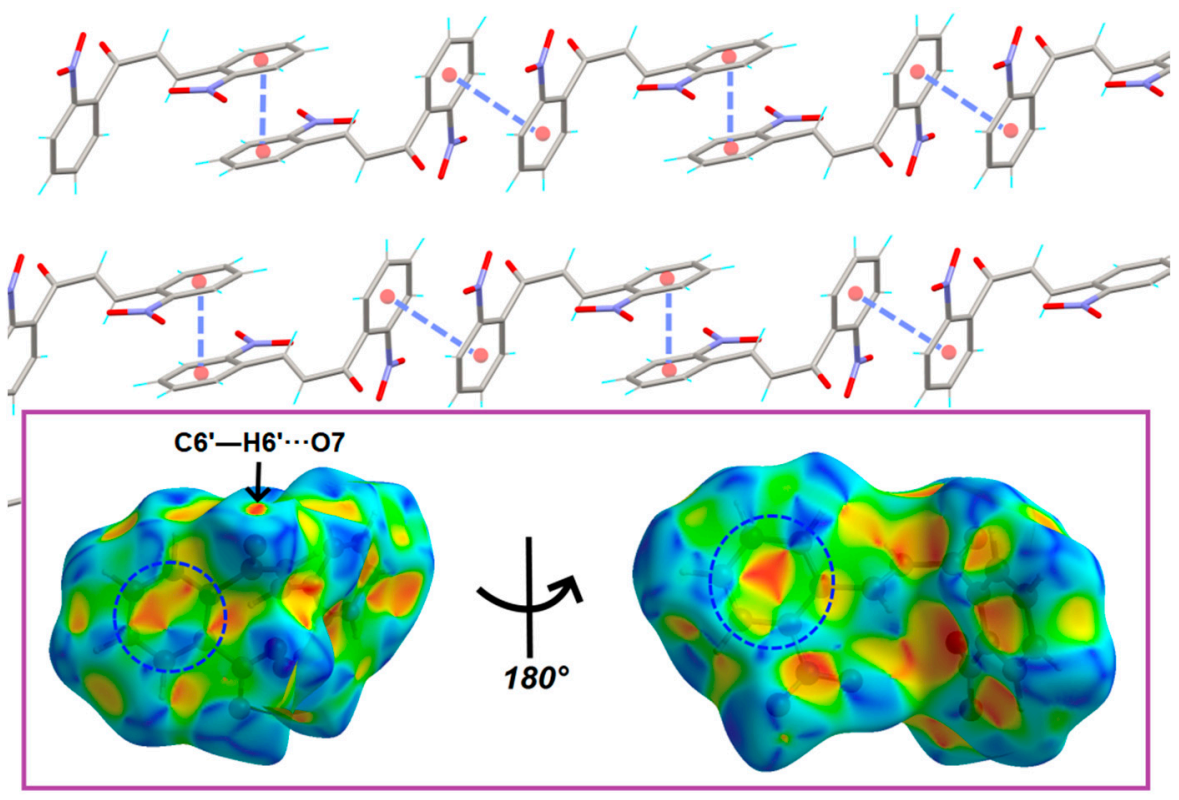

Figure 4. Part of the crystal structure of 1a, showing the main intermolecular interactions. The inset shows the Hirshfeld surface mapped with the shape index property (-1.0 to $1.0 \mathrm{a.u}$ ) highlighting blue regions around bright-red spots within compound 1a. The aromatic-rings involved in stacking interactions are highlighting by dashed blue circles.

It must be considered that the main supramolecular feature of $\mathbf{1 a}$ is the $\pi$-stacking between the chalcone molecules; we have calculated the Hirshfeld surface with CrystalExplorer 17.5 [46], but instead of using the $d_{\text {norm }}$ function (commonly used to characterize $\mathrm{N}-\mathrm{H} \cdots \mathrm{O}$ or $\mathrm{O}-\mathrm{H} \cdots \mathrm{O}$ hydrogen-bonds), we use the shape index property to identify planar stacking arrangements [47-49]. In a shape index function mapped on a Hirshfeld surface, the red hollows indicate noncovalent forces such as weak hydrogen bonds or aromatic interactions, while the blue bumps indicate spaces between neighboring molecules with little or no interaction [48].

In compound 1a the red hollows are located on electronegative regions, which are involved in short contacts via $\mathrm{C}-\mathrm{H} \cdots \mathrm{O}$ hydrogen bonds. In other words, the $\mathrm{C} 6^{\prime}$ from aromatic ring (outside the surface) establishes a weak aromatic hydrogen-bond with $\mathrm{O} 7$ atom from carbonyl group as an acceptor with distance $\mathrm{C}^{\prime}-\mathrm{H} 6^{\prime} \cdots \mathrm{O} 7$ of 2.60 (7) $\AA$ (inside the surface). This weak interaction is represented in the shape index as a small red depression (Figure 4). On the other hand, the pattern of blue and red triangles over both aromatic systems is strong evidence for close C $\cdots C$ interplanar contacts, while the green and yellow regions surrounding the aromatic rings are caused by the symmetrical effect of the nitro- 
groups (Figure 4, inset). The C $\cdots C$ stacking interactions represent $6.2 \%$ of the all interactions contained in the crystal according to the 2D-fingerprint plot (Figure S11) [50,51].

In the crystal of compound $\mathbf{1 b}$, the molecules also are held together via short $\mathrm{C}-\mathrm{H} \cdots \mathrm{O}$ contacts, where the $\mathrm{O}$ atoms from carbonyl and nitro groups serve as acceptor groups. In a similar way to compound $1 \mathbf{a}$, the $\pi$-stacking interactions seem to dominate the crystal packing. The molecules are packing in dimers, favoring the interaction between the planar moieties. In this way, the $\mathrm{C} 1-\mathrm{C} 6$ aromatic rings are stacked in a parallel-displaced fashion with a distance of 3.862(13) A between the centroids of two inversion-related aromatic rings (Figure 5). The blue and red triangular region on the $\mathrm{C} 1-\mathrm{C} 6$ aromatic ring in the shape index surface confirms the C $\cdots C$ stacking interactions between these systems (Figure 5, inset). The supramolecular assembly is additionally supported by weak $\mathrm{C}-\mathrm{H} \cdots \pi$ interactions, implicating the phenyl rings. According to the shape index property, these contacts are observed as a large red depression caused by the proximity of the $\mathrm{C}^{\prime}-\mathrm{C}^{\prime}$ aromatic ring to the $\mathrm{C} 1-\mathrm{C} 6$ system.

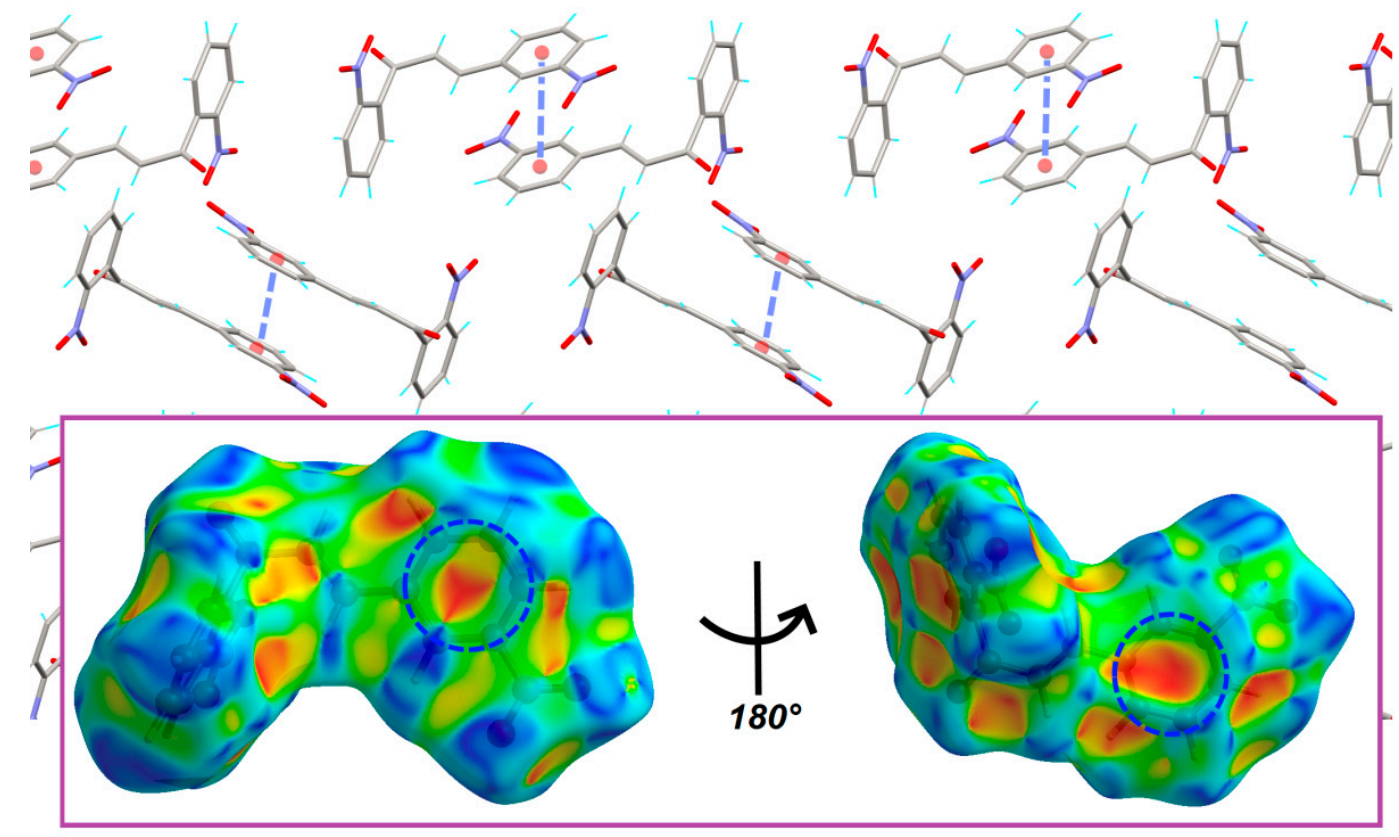

Figure 5. Part of the crystal structure of $\mathbf{1 b}$, showing intermolecular interactions between the molecules. The inset shows the Hirshfeld surface mapped with the shape index property (-1.0 to $1.0 \mathrm{a}$.u), highlighting blue regions around bright-red spots within compound $\mathbf{1 b}$. The aromatic-rings involved in aromatic interactions are highlighting by dashed blue circles.

Due to the planar geometry of compound $\mathbf{1 c}$, the crystal structure is characterized by a sheet-like alignment of molecules running parallel to the [101] direction. Each layer is formed by inversion-related molecules interacting through $\mathrm{C}-\mathrm{H} \cdots \mathrm{O}$ short contacts, forming $R_{2}^{2}(16)$ and $R_{4}^{4}(20)$ graph-set motifs according to Etter's nomenclature (Figure 6) [52,53]. These infinite layers are stacked on each other, showing additional intermolecular $\pi-\pi$ stacking interactions between the $\mathrm{C}^{\prime}-\mathrm{C}^{\prime}$ aromatic rings with a centroid-to-centroid distance of 3.80(4) $\AA$, stabilizing the crystal packing in direction of the crystallographic $a$-axis. The Hirshfeld surface mapped over $d_{\text {norm }}$ shows red spots where the contacts are shorter than vdW separations [48-54]. Regarding compound 1c, these spots are related to regions occupied by the nitro and carbonyl groups, which are involved in weak $\mathrm{C}-\mathrm{H} \cdots \mathrm{O}$ hydrogen bonds with neighboring molecules (see inset, Figure 6). These noncovalent interactions represent ca. $50 \%$ of all interactions in the crystal, considering reciprocal contacts, according to the 2D fingerprint plot (Figure S12). 


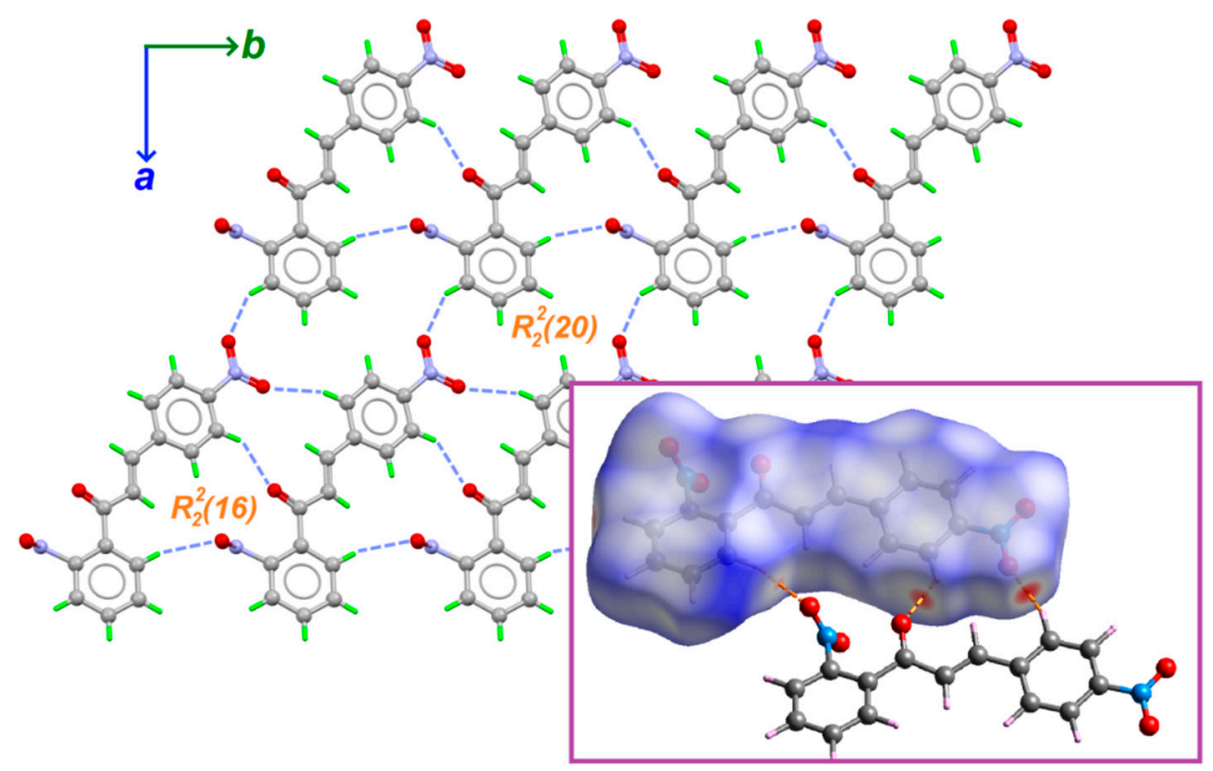

Figure 6. View of the 2D layer structure of $1 \mathrm{c}$ in the ab plane. The inset displays the Hirshfeld surface mapped on $d_{\text {norm }}$ property ( -0.22 to $1.27 \AA$ ), where the orange dashed lines show the contacts of $\mathrm{C}-\mathrm{H} \cdots \mathrm{O}$ with a neighboring chalcone molecule.

\section{Conclusions}

In summary, we have successfully prepared chalcones containing the $-\mathrm{NO}_{2}$ group. Crystal structures show that $\mathbf{1 a}$ and $\mathbf{1 b}$ exhibit s-trans conformation, while $\mathbf{1 c}$ isomer crystallized in the s-cis conformation. Varying the position of the nitro group on the aromatic B-ring produces a direct effect on the molecular coplanarity and consequently, on the crystal packing. The chalcone $1 \mathrm{c}$ with the nitro group at the para position showed better molecular coplanarity between aromatic rings and the enone moiety. Intermolecular close contacts in the crystal structures of $\mathbf{1 a} \mathbf{- 1} \mathbf{c}$ by Hirshfeld surface analysis were visualized and quantified. Intermolecular $\pi$-stacking (in 1a-1b) and $\mathrm{C}-\mathrm{H} \cdots \mathrm{O}$ (in 1c) interactions are the most important contributors to the crystal packing.

Supplementary Materials: The following are available online at https:/ /www.mdpi.com/article/ 10.3390/cryst11121589/s1, Figure S1: 1H NMR (600 MHz, DMSO-d6) of compound 1a, Figure S2: DEPTQ NMR (150 MHz, DMSO-d6) of compound 1a, Figure S3: ${ }^{1} \mathrm{H}$ NMR (600 MHz, DMSO-d6) of compound 1b, Figure S4: DEPTQ NMR (150 MHz, DMSO-d6) of compound 1b, Figure S5: ${ }^{1} \mathrm{H}$ NMR (600 MHz, DMSO-d6) of compound 1c, Figure S6: DEPTQ NMR (150 MHz, DMSO-d6) of compound 1c, Figure S7: FT-IR Spectrum of 1a-1c, Figure S8: A view of the crystal packing down the b axis for compound 1a, Figure S9: A view of the crystal packing down the b axis for compound $1 \mathbf{b}$, Figure S10: A view of the crystal packing down a axis for compound 1c, Figure S11: The two-dimensional fingerprint plot of 1a, Figure S12: The two-dimensional fingerprint plot of 1c, Table S1: Assignment of characteristic vibrational frequencies for $\mathbf{1 a}-\mathbf{1 c}$, Table S2: Selected Bond lengths $[\AA \AA]$ and angles $\left[{ }^{\circ}\right]$ for 1a, Table S3: Selected Bond lengths $[\AA]$ and angles $\left[{ }^{\circ}\right]$ for $\mathbf{1 b}$, Table S4: Selected Bond lengths $[\AA]$ and angles $\left[^{\circ}\right]$ for $\mathbf{1 c}$, Table S5: Hydrogen-bond for 1a, Table S6: Hydrogen-bond for $\mathbf{1 b}$, Table S7: Hydrogen -bonds for $\mathbf{1 c}$.

Author Contributions: Conceptualization and methodology: N.R.-C., M.A.V.-R. and A.Y.H.; Software and validation: E.S.-L. and C.A.; Formal analysis, investigation, resources: A.Y.H., A.G.-R., R.L.-R. and M.H.-R. Data curation writing-original: A.Y.H., E.S.-L. and M.V. Draft preparation, and writing-review and editing: C.E.L.-G., N.R.-C., A.G.-R. and R.L.-R., Visualization: M.V. and C.A.; Supervision, project administration and funding acquisition: A.G.-R., C.E.L.-G., M.A.V.-R., C.A. and N.R.-C. All authors have read and agreed to the published version of the manuscript.

Funding: The authors are grateful to PRODEP and CONACyT by financial support provided for this research by the projects: UJAT-EXB-242, CONACyT-226155 and CONACyT-268178.

Institutional Review Board Statement: Not applicable. 
Informed Consent Statement: Not applicable.

Data Availability Statement: All data have been included in Supplementary Materials.

Acknowledgments: A.Y.H. wish to thank CONACyT (Mexico) for the fellowship support number 861538. M.V. was supported by PRODEP postdoctoral fellowship (14812). R.L.-R. (478597) was supported by CONACyT postdoctoral fellowship (866998). The authors acknowledge Sylvain Bernès for carrying out the X-ray diffraction experiment performed on a Stoe Stadivari diffractometer, and for the refinement process of the reported crystal structures.

Conflicts of Interest: The authors declare no conflict of interest.

\section{References}

1. Zhuang, C.; Zhang, W.; Sheng, C.; Zhang, W.; Xing, C.; Miao, Z. Chalcone: A privileged structure in medicinal chemistry. Chem. Rev. 2017, 117, 7762-7810. [CrossRef]

2. Rammohan, A.; Reddy, J.S.; Sravya, G.; Rao, C.N.; Zyryanov, G.V. Chalcone synthesis, properties and medicinal applications: A review. Environ. Chem. Lett. 2020, 18, 433-458. [CrossRef]

3. Rozmer, Z.; Perjési, P. Naturally occurring chalcones and their biological activities. Phytochem. Rev. 2016, 15, 87-120. [CrossRef]

4. Rivière, C. Dihydrochalcones: Occurrence in the plant kingdom, chemistry and biological activities. In Studies in Natural Products Chemistry; Atta-ur-Rahman, Ed.; Elsevier: Amsterdam, The Netherlands, 2016; Volume 51, Chapter 7; pp. $253-381$.

5. Sharma, V.; Singh, G.; Kaur, H.; Saxena, A.K.; Ishar, M.P.S. Synthesis of $\beta$-ionone derived chalcones as potent antimicrobial agents. Bioorg. Med. Chem. Lett. 2012, 22, 6343-6346. [CrossRef] [PubMed]

6. Bondock, S.; Naser, T.; Ammar, Y.-A. Synthesis of some new 2-(3-pyridyl)-4,5-disubstituted thiazoles as potent antimicrobial agents. Eur. J. Med. Chem. 2013, 62, 270-279. [CrossRef]

7. Damazio, R.G.; Zanatta, A.P.; Cazarolli, L.H.; Mascarello, A.; Chiaradia, L.D.; Nunes, R.J.; Yunes, R.A.; Silva, F.R.M.B. Nitrochalcones: Potential in vivo insulin secretagogues. Biochimie 2009, 91, 1493-1498. [CrossRef]

8. Tajammal, A.; Batool, M.; Ramzan, A.; Samra, M.M.; Mahnoor, I.; Verpoort, F.; Irfan, A.; Al-Sehemi, A.G.; Munawar, M.A.; Basra, M.A.R. Synthesis, antihyperglycemic activity and computational studies of antioxidant chalcones and flavanones derived from 2 , 5 dihydroxyacetophenone. J. Mol. Struct. 2017, 1148, 512-520. [CrossRef]

9. Higgs, J.; Wasowski, C.; Marcos, A.; Jukič, M.; Paván, C.H.; Gobec, S.; de Tezanos Pinto, F.; Colettis, N.; Marder, M. Chalcone derivatives: Synthesis, in vitro and in vivo evaluation of their anti-anxiety, anti-depression and analgesic effects. Heliyon 2019, 5, e01376. [CrossRef]

10. Zhang, B.; Duan, D.; Ge, C.; Yao, J.; Liu, Y.; Li, X.; Fang, J. Synthesis of xanthohumol analogues and discovery of potent thioredoxin reductase inhibitor as potential anticancer agent. J. Med. Chem. 2015, 58, 1795-1805. [CrossRef]

11. Mai, C.W.; Yaeghoobi, M.; Abd-Rahman, N.; Kang, Y.B.; Pichika, M.R. Chalcones with electron-withdrawing and electrondonating substituents: Anticancer activity against TRAIL resistant cancer cells, structure-activity relationship analysis and regulation of apoptotic proteins. Eur. J. Med. Chem. 2014, 77, 378-387. [CrossRef]

12. Jardim, G.A.M.; Guimarães, T.T.; Pinto, M.C.F.R.; Cavalcanti, B.C.; de Farias, K.M.; Pessoa, C.; Gatto, C.C.; Nair, D.K.; Namboothiri, I.N.N.; da Silva Júnior, E.N. Naphthoquinone-based chalcone hybrids and derivatives: Synthesis and potent activity against cancer cell lines. Med. Chem. Commun. 2015, 6, 120-130. [CrossRef]

13. Bandeira, P.N.; Lemos, T.L.G.; Santos, H.S.; Carvalho, M.C.S.; Pinheiro, D.P.; Morais-Filho, M.O.; Pessoa, C.; Barros-Nepomuceno, F.W.A.; Rodrigues, T.H.; Ribeiro, P.R.V.; et al. Synthesis, structural characterization, and cytotoxic evaluation of chalcone derivatives. Med. Chem. Res. 2019, 28, 2037. [CrossRef]

14. Gómez-Rivera, A.; Aguilar-Mariscal, H.; Romero-Ceronio, N.; Roa-de la Fuente, L.F.; Lobato-Garcia, C.E. Synthesis and antiinflammatory activity of three nitro chalcones. Bioorg. Med. Chem. Lett. 2013, 23, 5519-5522. [CrossRef]

15. Zhang, G.; Lin, L.; Yang, K.; Wang, S.; Feng, Q.; Zhu, J.; Song, Q. 3-Aminoindole Synthesis from 2-Nitrochalcones and Ammonia or Primary Amines. Adv. Synth. Catal. 2019, 361, 3718-3722. [CrossRef]

16. Nguyen, T.B.; Retailleau, P. Cooperative Activating Effect of Tertiary Amine-DMSO on Elemental Sulfur: Direct Access to Thioaurones from 2'-Nitrochalcones under Mild Conditions. Org. Lett. 2018, 20, 186-189. [CrossRef]

17. Poudel, T.N.; Lee, Y.R. Construction of highly functionalized carbazoles via condensation of an enolate to a nitro group. Chem. Sci. 2015, 6, 7028-7033. [CrossRef]

18. González, J.F.; Rocchi, D.; Tejero, T.; Merino, P.; Menéndez, J.C. One-Pot Synthesis of Functionalized Carbazoles via a CANCatalyzed Multicomponent Process Comprising a C-H Activation Step. J. Org. Chem. 2017, 82, 7492-7502. [CrossRef] [PubMed]

19. Nguyen, T.B.; Retailleau, P. Redox-Neutral Access to Sultams from 2-Nitrochalcones and Sulfur with Complete Atom Economy. Org. Lett. 2017, 19, 3879-3882. [CrossRef]

20. Nguyen, T.B.; Retailleau, P. DIPEA-Promoted Reaction of 2-Nitrochalcones with Elemental Sulfur: An Unusual Approach to 2Benzoylbenzothiophenes. Org. Lett. 2017, 19, 4858-4860. [CrossRef]

21. Umeda, R.; Kouno, H.; Kitagawa, T.; Okamoto, T.; Kawashima, K.; Mashino, T.; Nishiyama, Y. Selective Synthesis of Quinolines and Indoles: Sulfur-Assisted or Selenium-Catalyzed Reaction of $\beta$-(2-Nitrophenyl)- $\alpha$, $\beta$-Unsaturated Ketones with Carbon Monoxide. Heteroat. Chem. 2014, 25, 698-703. [CrossRef] 
22. Lin, Z.; Hu, Z.; Zhang, X.; Dong, J.; Liu, J.-B.; Chen, D.-Z.; Xu, X. Tandem Synthesis of Pyrrolo[2,3-b]quinolones via Cadogen-Type Reaction. Org. Lett. 2017, 19, 5284-5287. [CrossRef]

23. Aksenov, N.A.; Aksenov, D.A.; Arutiunov, N.A.; Aksenova, D.S.; Aksenov, A.V.; Rubin, M. Unexpected Cyclization of orthonitrochalcones into 2-Alkylideneindolin-3-ones. RSC Adv. 2020, 10, 18440-18450. [CrossRef]

24. Shan, Y.; Liu, Z.; Cao, D.; Sun, Y.; Wang, K.; Chen, H. Nitro substituted chalcone derivatives as quick-response chemosensors for cyanide anions. Sens. Actuators B Chem. 2014, 198, 15-19. [CrossRef]

25. Simon, F.-X.; Nguyen, T.-T.-T.; Schmutz, M.; Decher, G.; Nicoud, J.-F.; Mésini, P.J. Nitrochalcones as organogelators: Evidence of the involvement of nitro groups and solvent in gel formation. New J. Chem. 2009, 33, 2028-2033. [CrossRef]

26. Stoe \& Cie. X-AREA and X-RED32; Stoe \& Cie: Darmstadt, Germany, 2009.

27. Sheldrick, G.M. Crystal structure refinement with SHELXL. Acta Crystallogr. Sect. C Struct. Chem. 2015, 71, 3-8. [CrossRef]

28. Farrugia, L.J. WinGX and ORTEP for Windows: An update. J. Appl. Crystallogr. 2012, 45, 849-854. [CrossRef]

29. Macrae, C.F.; Sovago, I.; Cottrell, S.J.; Galek, P.T.A.; McCabe, P.; Pidcock, E.; Platings, M.; Shields, G.P.; Stevens, J.S.; Towler, M.; et al. Mercury 4.0: From visualization to analysis, design and prediction. J. Appl. Crystallogr. 2020, 53, 226-235. [CrossRef] [PubMed]

30. Spek, A.L. Single-crystal structure validation with the program PLATON. J. Appl. Crystallogr. 2003, 36, 7-13. [CrossRef]

31. Groom, C.R.; Allen, F.H. The Cambridge Structural Database in retrospect and prospect. Angew. Chem. Int. Ed. 2014, 53, 662-671. [CrossRef] [PubMed]

32. Kinkle, P.; Gibian, H. Uber Chalkone. Chem. Ber. 1961, 94, 26-38.

33. Prabhu, S.R.; Jayarama, A.; Chandrasekharan, K.; Upadhyaya, V. Synthesis, growth, structural characterization, Hirshfeld analysis and nonlinear optical studies of a methyl substituted chalcone. J. Mol. Struct. 2007, 1136, 244-252. [CrossRef]

34. Gomes, M.N.; Muratov, E.N.; Pereira, M.; Peixoto, J.C.; Rosseto, L.P.; Cravo, P.V.L.; Andrade, C.H.; Neves, B.J. Chalcone derivatives: Promising starting points for drug design. Molecules 2017, 22, 1210. [CrossRef] [PubMed]

35. Bruno, I.J.; Cole, J.C.; Kessler, M.; Luo, J.; Sam Motherwell, W.D.; Parkis, L.H.; Smith, B.R.; Taylor, R.; Copper, R.I.; Harris, S.E.; et al. Retrieval of Crystallographic-Derived Molecular Geometry Information. J. Chem. Inf. Comput. Sci. 2004, 44, $2133-2144$. [CrossRef] [PubMed]

36. Jungk, A.E.; Schmidt, G.M.J. Conformational studies. Part II. Crystal and molecular structures of 3-bromo-, 3-chloro-, and 4-bromo-2'-nitrochalcone. J. Chem. Soc. B Phys. Org. 1970, 1427-1434. [CrossRef]

37. Carpy, A.; Leger, J.M.; Nuhrich, A. 1-(2-nitrophenyl)-3-(5-nitro-2-furanyl)-2-propen-1-one, $\mathrm{C}_{13} \mathrm{H}_{8} \mathrm{~N}_{2} \mathrm{O}_{6}$. Cryst. Struct. Commun. 1978, 7, 361-364.

38. Jezuita, A.; Ejsmont, K.; Szatylowicz, H. Substituent effects of nitro group in cyclic compounds. Struct. Chem. 2021, 32, 179-203. [CrossRef]

39. Hussein, H.A.; Fadhil, G.F. Theoretical investigation of para amino-dichloro chalcone isomers, part I: A DFT structure-stability study. J. Phys. Org. Chem. 2020, 33, e4073. [CrossRef]

40. Zainuri, D.A.; Razak, I.A.; Arshad, S. Molecular structure, DFT studies and UV-Vis absorption of two new linear fused ring chalcones:(E)-1-(anthracen-9-yl)-3-(2-methoxyphenyl) prop-2-en-1-one and (E)-1-(anthracen-9-yl)-3-(3-fluoro-4-methoxyphenyl) prop-2-en-1-one. Acta Crystallogr. Sec. E Crystallog. Commun. 2018, 74, 1087-1092. [CrossRef]

41. Ramos, R.R.; da Silva, C.C.; Guimarães, F.F.; Martins, F.T. Polymorphism and conformerism in chalcones. CrystEngComm 2016, 18, 2144-2154. [CrossRef]

42. Yu, F.; Wang, M.; Sun, H.; Shan, Y.; Du, M.; Khan, A.; Usman, R.; Zhang, W.; Shan, H.; Xu, C. Tunning the Solid-State Fluoresence of Chalcone Crystals via Molecular Coplanarity and J-Aggregate. RSC Adv. 2017, 7, 8491-8503. [CrossRef]

43. Almeida, L.R.; Anjos, M.M.; Ribeiro, G.C.; Valverde, C.; Machado, D.F.S.; Oliveira, G.R.; Napolitano, H.B.; de Oliveira, H.C.B. Synthesis, structural characterization and computational study of a novel amino chalcone: A potential nonlinear optical material. New J. Chem. 2017, 41, 1744-1754. [CrossRef]

44. Kumar, C.S.C.; Loh, W.S.; Ooi, C.W.; Quah, C.K.; Fun, H.K. Heteroaryl chalcones: Design, synthesis, X-ray crystal structures and biological evaluation. Molecules 2013, 18, 12707-12724. [CrossRef] [PubMed]

45. Bakarić, D.; Baranović, G. The conformational equilibrium and vibrational properties of chalcone. J. Mol. Struct. 2019, 1196, 429-438. [CrossRef]

46. Spackman, P.R.; Turner, M.J.; Mckinnon, J.J.; Wolff, S.K.; Grimwood, D.J.; Jayatilaka, D.; Spackman, M.A. CrystalExplorer: A program for Hirshfeld surface analysis, visualization and quantitative analysis of molecular crystal. J. Appl. Cryst. 2021, 54, 1006-1011. [CrossRef] [PubMed]

47. Mackenzie, C.F.; Spackman, P.R.; Jayatilaka, D.; Spackman, M.A. CrystalExplorer Model Energies and Energy Frameworks: Extension to Metal Coordination Compounds, Organic Salts, Solvates and Open-Shell Systems. IUCrJ 2017, 4, 575-587. [CrossRef]

48. Spackman, M.A.; Jayatilaka, D. Hirshfeld surface analysis. CrystEngComm 2009, 11, 19-32. [CrossRef]

49. Tan, S.L.; Jotani, M.M.; Tiekink, E.R. Utilizing Hirshfeld surface calculations, non-covalent interaction (NCI) plots and the calculation of interaction energies in the analysis of molecular packing. Acta Crystallogr. Sec. E Crystallog. Commun. 2019, 75, 308-318. [CrossRef] [PubMed]

50. Parkin, A.; Barr, G.; Dong, W.; Gilmore, C.J.; Jayatilaka, D.; Mckinnon, J.J.; Spackman, M.A.; Wilson, C.C. Comparing entire crystal structure: Structural genetic fingerprint. CrystEngComm 2007, 9, 648-652. [CrossRef] 
51. Spackman, M.A.; McKinnon, J.J. Fingerprinting intermolecular interactions in molecular crystals. CrystEngComm 2002, 4, 378-392. [CrossRef]

52. Etter, M.C.; MacDonald, J.C.; Bernstein, J. Graph-Set Analysis of Hydrogen-Bond Patterns in Organic Crystals. Acta Crystallogr. Sect. B Struct. Sci. 1990, 46, 256-262. [CrossRef] [PubMed]

53. Etter, M.C. Encoding and decoding hydrogen-bond patterns of organic compounds. Acc. Chem. Res. 1990, 23, 120-126. [CrossRef]

54. McKinnon, J.J.; Jayatilaka, D.; Spackman, M.A. Towards Quantitative Analysis of Intermolecular Interactions with Hirshfeld Surfaces. Chem. Commun. 2007, 3814-3816. [CrossRef] [PubMed] 